Syntax Literate: Jurnal Ilmiah Indonesia p-ISSN: 2541-0849

e-ISSN: 2548-1398

Vol. 6, No. 5, Mei 2021

\title{
FIGUR PEMIMPIN AUTENTIK DALAM MENUNJANG KREATIVITAS PEKERJA MEDIA DI INDUSTRI TELEVISI
}

\author{
Chindy Y Subandrio dan Anissa Lestari Kadiyono
}

Universitas Padjajaran (UNPAD) Bandung Jawa Barat, Indonesia

Email: chindy.subandrio@gmail.com dan anissa.lestari@unpad.ac.id

\begin{abstract}
Authentic leadership can result in greater self-awareness, encouraging positive behavior and positive self-development in organizational settings. The authenticity of the leader is a manifestation of the dimension of self-awareness, transparency of relationships, balanced information processing, and internalized moral perspectives, Leadership authenticity can foster positive behavior from existing human resources, including creativity. The definition of creativity is a process to cultivate or generate or instruct an idea, idea, or solution that has a newness and beneficial value. Therefore, this research aims to determine the correlation between authentic leadership and creativity of employees in $X$ television media office. This study uses total sampling technique. There were 30 of research participants consisting of organic employees and affiliated contributors on X media TV office in West Java. Authentic leadership is measured using ALQ (Authentic Leadership Questionnaire), while employee creativity is measured by using the scale of creativity. The results showed that there was a significant positive correlation between the authentic leadership and employees creativity.
\end{abstract}

Keywords: authentic leadership; creativity; media workers

\section{Abstrak}

Kepemimpinan autentik dapat menghasilkan kesadaran diri yang lebih besar, mendorong perilaku positif, serta mendorong perkembangan diri yang positif pada pegawai dalam suatu setting organisasi. Autentisitas pemimpin merupakan manifestasi dari dimensi kesadaran diri, transparansi hubungan, pemrosesan informasi berimbang, dan internalisasi perspektif moral. Autentisitas pemimpin dapat menumbuhkan perilaku positif dari Sumber Daya Manusia, salah satunya adalah kreativitas. Kreativitas merupakan suatu proses untuk menumbuhkan atau menghasilkan atau mengonstruksikan suatu ide, gagasan, ataupun solusi yang memiliki nilai kebaharuan dan bermanfaat. Penelitian ini bertujuan untuk mengetahui korelasi antara kepemimpinan autentik dengan kreativitas pegawai yang bekerja di kantor media televisi X. Kepemimpinan autentik merupakan gaya kepemimpinan yang belum banyak di teliti di Indonesia. Dari dimensi yang terkandung didalamnya, figur kepemimpinan autentik diperlukan sebagai faktor penunjang kreativitas para pekerja media. Penelitian ini menggunakan teknik pengambilan sampel total (total sampling). Terdapat 30 partisipan penelitian yang terdiri dari pegawai organik dan kontributor yang terafilisasi dengan kantor media TV X di Jawa Barat. Kepemimpinan autentik diukur dengan menggunakan

$\begin{array}{ll}\text { How to cite: } & \text { Subandrio, Chindy Y., dan Anissa Lestari Kadiyono (2021) Figur Pemimpin Autentik Dalam } \\ & \text { Menunjang Kreativitas Pekerja Media di Industri Televisi, Syntax Literate. 6(5). } \\ & \text { http://dx.doi.org/10.36418/syntax-literate.v6i5.2732 } \\ \text { E-ISSN: } & 2548-1398 \\ \text { Published by: } & \text { Ridwan Institute }\end{array}$


Authentic Leadership Questionnaire. Kreativitas pegawai diukur dengan menggunakan skala kreativitas. Hasil penelitian menunjukkan bahwa terdapat hasil korelasi positif yang signifikan antara tipe kepemimpinan autentik dengan kreativitas pegawai.

Kata Kunci: kepemimpinan autentik; kreativitas; pekerja media

\section{Pendahuluan}

Penyebaran informasi berita saat ini berlangsung dengan sangat cepat seiring dengan mudahnya khalayak dalam mengakses sumber-sumber berita. Penyampaian informasi melalui media massa seperti surat kabar, televisi, radio, dan sejumlah media lainnya telah banyak membentuk pengetahuan dan pendapat masyarakat tentang berbagai peristiwa terkini. Media massa telah hadir ditengah-tengah masyarakat tanpa adanya batasan waktu dan jarak, bahkan kehadiran media massa juga dianggap dapat mempengaruhi cara hidup seseorang. Diantara berbagai media massa yang ada,media televisi merupakan salah satu media paling efektif dalam menyampaikan informasi kepada masyarakat (Ishwara, 2005). Informasi saat ini menjadi suatu kebutuhan yang sangat penting dan tidak dapat dipisahkan dari kehidupan manusia. Rasa ingin tahu yang merupakan sifat dasar manusia menjadi faktor pendorong terbesar akan kebutuhan tersebut. Manusia mencari informasi untuk berbagai tujuan hidup. Selain menambah pengetahuan yang dapat memperluas cakrawala berpikir, informasi juga berperan sebagai salah satu sumber pertimbangan dalam pengambilan keputusan.

Sebagai penyedia informasi, media massa memerlukan adanya proses kerja kolaboratif antar komponen yang terlibat didalamnya. Pekerja media memiliki tugas penting yaitu mengolah informasi yang berguna dan memilah informasi yang sesuai dengan kaidah jurnalistik (Ishwara, 2005). Bekerja didalam lingkungan media memiliki tantangan yang cukup berat, banyak kendala yang sering muncul dalam usaha mengumpulkan informasi untuk disajikan dalam sebuah berita, diantaranya waktu yang terbatas, sulitnya mendapatkan sudut pandang dari peristiwa yang diliput, serta sumbersumber yang tidak kooperatif. Oleh karenanya diperlukan upaya-upaya kreatif bagi individu yang berkecimpung didalamnya agar dapat menjawab tantangan pekerjaan dan selalu bersesuaian dengan peran mereka sebagai pekerja media.

Iklim kerja yang berproses secara kreatif merupakan representasi dari keberhasilan pengelolaan suatu industri. Proses kreatif dalam lingkungan kerja merupakan citra dari kreativitas individu-individu yang berada dalam lingkungan tersebut. Kreativitas tidak hanya dapat dimaknai sebagai suatu proses dalam menciptakan ide atau gagasan baru, akan tetapi kreativitas adalah kemampuan berpikir divergen, konvergen, dan evaluatif untuk menjajaki bermacam-macam alternatif jawaban terhadap suatu persoalan (Guilford, 1968). Menurut (George \& Zhou, 2007), kreativitas merupakan suatu proses untuk menumbuhkan atau menghasilkan atau mengkonstruksikan suatu ide, gagasan, ataupun solusi yang memiliki nilai kebaharuan dan bermanfaat. Kreativitas itu sendiri dapat dipengaruhi oleh sejumlah faktor, salah 
satu faktor yang memainkan peran dalam menumbuhkan kreativitas pada lingkungan kerja adalah gaya atau tipe kepemimpinan.

Beberapa penelitian menyebutkan bahwa peran pemimpin dalam hal ini gaya kepemimpinan, memiliki kontribusi terhadap kreatifitas pegawai. Menurut (Bosiok, 2013) tipe kepemimpinan otokratik, demokratik dan liberal memiliki hubungan yang signifikan dengan kreatifitas pegawai. Lebih lanjut, (Herrmann \& Felfe, 2014) juga menemukan bahwa tipe kepemimpinan transformasional merupakan prediktor yang lebih baik dalam menstimulasi kreatifitas pada pegawai dibandingkan dengan tipe kepemimpinan transaksional. Beberapa penelitian tersebut menyiratkan bahwa fungsi pemimpin bukan hanya menentukan dan mengelola keberlagsungan suatu organisasi dalam mencapai tujuan yang telah disepakati, (Winston \& Patterson, 2006) menyatakan bahwa definisi mengenai kepemimpinan seyogianya dapat disusun dengan lebih kompleks, dengan menambahkan suatu konsep bahwa kepemimpinan merupakan proses membuat followers menjadi inovatif, mampu mengarahkan diri sendiri dalam ranah tugas kerja dan membuat followers dapat menjadi lebih mandiri dalam mencapai keberhasilan, menemukan kesalahan dan kegagalan selama dalam proses memenuhi tujuan organisasi. Berdasarkan hal tersebut, dapat diketahui bahwa ada tipe-tipe kepemimpinan tertentu yang dapat meningkatkan kreatifitas pada pegawai.

Menurut (Müceldili, Turan, \& Erdil, 2013) pemimpin yang mampu menjalin hubungan secara transparan dengan pegawai dapat membuat pegawai menjadi lebih terbuka terhadap pemikiran-pemikiran baru yang pada akhirnya menunjang proses berpikir kreatif mereka. Transparansi hubungan menekankan pada pola relasi yang baik dan terjaga, antara pemimpin dan karyawan. Transparansi hubungan terjadi apabila mampu membagikan perasaan, motivasi, dan keinginan hati dengan orang lain secara tepat berlandaskan ketulusan dan kejujuran.

Pemimpin yang mampu menganalisa semua informasi yang relevan secara objektif sebelum membuat keputusan seperti menganalisa fakta, data, baik internal dan self-reference, menunjukkan bahwa pemimpin tersebut tidak melebih-lebihkan atau mengabaikan informasi, serta menganalisa data penting secara objektif sebelum membuat keputusan (Walumbwa et al., 2008). Menanggapi hal tersebut, (Rego, Sousa, Marques, \& e Cunha, 2012) menilai bahwa pemimpin yang menjalin hubungan secara transparan dan berpikiran terbuka, cenderung lebih mampu menerima gagasan-gagasan kreatif dari para karyawannya dan tidak menganggap hal tersebut sebagai ancaman bagi karirnya. (Mubarak \& Noor, 2018) mengungkapkan bahwa pemimpin yang mampu menyelaraskan antara tindakan dan keyakinan, merefleksikan konsep pemimpin yang autentik.

(Hebbeln, 2020) memaparkan bahwa beberapa peneliti telah mengkaji bagaimana para jurnalis dan pekerja media bekerja dalam iklim yang serba cepat, harus menghadapi emosi mereka sendiri pada saat bertugas ditengah berbagai pemicu stres lain dalam kehidupannya, mulai dari pekerjaan hingga berbagai bobot berita yang mereka tampilkan (Hebbeln, 2020). para karyawan media membutuhkan sosok pemimpin autentik, sosok pemimpin yang tidak melebih-lebihkan atau mengabaikan 
informasi dari para karyawannya, setiap hendak mengambil keputusan selalu berdasarkan analisa fakta dan data, pemimpin yang transparan dan berpikiran terbuka, serta percaya dengan kemampuannya, sehingga tidak merasa terancam (insecure) dengan kehadiran ide-ide baru dari para karyawan yang bisa jadi berasal dari kelompok generasi yang berbeda dengan dirinya. Temuan dalam penelitian (Campbell, Knox, Rowlands, Cui, \& DeJesus, 2021) mengungkapkan bahwa kepemimpinan autentik dalam industri atau organisasi apa pun dapat ditingkatkan dan dieksplorasi lebih lanjut, karena memiliki dampak positif pada inovasi dalam organisasi yang pada gilirannya memiliki potensi untuk memberikan berbagai peluang untuk pertumbuhan dan keunggulan suatu organisasi.

Menurut (Semedo, Coelho, \& Ribeiro, 2017) kepemimpinan autentik memiliki kontribusi terhadap kreativitas pegawai $(\mathrm{r}=0.40 ; \mathrm{p}<0.05)$. Konsep ini disusun berdasarkan 4 dimensi (Avolio \& Gardner, 2005) yaitu Komponen kesadaran diri (Selfawarenes), Pemrosesan Informasi Berimbang (Information Balanced Processing), Transparansi Hubungan (Relational Transparency) dan Internalisasi Perspektif Moral (Internalized Moral Perspective). Berkenaan dengan hal tersebut, (Avolio \& Gardner, 2005) mendefinisikan kepemimpinan autentik sebagai proses autentik dari seorang pemimpin yang menggambarkan dan memanfaatkan kapasitas psikologis secara positif dan memanfaatkan konteks perkembangan organisasi untuk tujuan menghasilkan kesadaran diri yang lebih besar, serta mendorong perilaku dan perkembangan diri yang positif dalam setting organisasional. Pada studi yang lebih lanjut, (Walumbwa et al., 2008) menambahkan bahwa kepemimpinan autentik merupakan pola perilaku pemimpin yang tidak hanya menggambarkan namun juga memanfaatkan kapasitas psikologis dan iklim etika yang positif. Penelitian ini bertujuan untuk mengetahui korelasi antara tipe kepemimpinan autentik (authentic leadership) dengan kreatifitas pegawai yang bekerja di kantor media televisi X Biro Jawa Barat.

\section{Metode Penelitian}

Penelitian ini menggunakan pendekatan kuantitatif dengan desain penelitian korelasi, studi korelasi dalam penelitian ini menggunakan uji somers'd. Uji somers'd digunakan untuk melihat hubungan dan koefisien determinasi antar variabel yang datanya bersifat non-parametrik (skala ordinal) (Riadi, 2016), dan diperoleh dari proses pengambilan sampel yang bersifat non-probabilistik. Korelasi rank spearman bertujuan untuk menjelaskan derajat dan bentuk hubungan antara variabel bebas dengan variabel terikat (Sugiyono, 2010).

\section{Hasil dan Pembahasan}

Tabel dibawah ini menunjukkan hasil analisis statistik deskriptif yang digunakan untuk memberikan gambaran umum mengenai data demografi responden: 
Tabel 1

Reliabilitas Instrumen

\begin{tabular}{llr}
\hline \multicolumn{1}{c}{ Instrumen } & \multicolumn{1}{c}{ Dimensi } & \multicolumn{1}{c}{$\boldsymbol{a}$} \\
\hline $\begin{array}{l}\text { Authentic Leadership Questionnaire } \\
\text { (ALQ) }\end{array}$ & Relational transparency & 0.77 \\
\cline { 2 - 3 } (Walumbwa et al., 2008) & Self-awareness & 0.73 \\
\cline { 2 - 3 } & Balanced Processing & 0.70 \\
\cline { 2 - 3 } & Internalized moral perspective & 0.73 \\
\hline \multirow{4}{*}{$\begin{array}{l}\text { Individual Level Creativity } \\
\text { (Zhou \& George, 2001) }\end{array}$} & Feedback valence & 0.69 \\
\cline { 2 - 3 } & Unclear ends & 0.79 \\
\cline { 2 - 3 } & Unclear means & 0.68 \\
\cline { 2 - 3 } & Multiple means & 0.74 \\
\hline
\end{tabular}

Tabel 2

Data Demografi Partisipan $(n=30)$

\begin{tabular}{ccc}
\hline & Pegawai Organik & Kontributor Terafiliasi \\
\hline Jenis Kelamin & & \\
\hline Laki-laki & 13 & 12 \\
\hline Perempuan & 3 & 2 \\
\hline Kelompok Usia & & 2 \\
\hline $20-29$ & 5 & 7 \\
\hline $30-39$ & 9 & 5 \\
\hline $40-49$ & 2 & 3 \\
\hline Masa Kerja & & 7 \\
\hline$<5$ tahun & 4 & 4 \\
\hline $5-10$ tahun & 9 & \\
\hline$>$ Tahun & 3 & \\
\hline
\end{tabular}

Hipotesis penelitian diuji dengan menggunakan uji korelasi Somers'd, untuk mengetahui apakah terdapat hubungan antara IV (Tipe Kepemimpinan Autentik) dengan DV (Kreativitas). Uji korelasi Somers'd digunakan sebab data pada penelitian ini bersifat non-parametrik dan diperoleh melalui proses pengambilan sampel secara non-probabilistik. Berikut tabel hasil uji korelasi Somers'd:

Tabel 3

Uji Korelasi Somers'd

\begin{tabular}{lcc}
\hline Variabel & $\boldsymbol{d}$ & $\boldsymbol{p}$ \\
\hline $\begin{array}{l}\text { Creativity } \\
\text { (Dependent) }\end{array}$ & 0.898 & 0.047 \\
\hline $\begin{array}{l}\text { Authentic Leadership } \\
\text { (Dependent) }\end{array}$ & 0.880 & 0.051 \\
\hline
\end{tabular}

Tabel 3 menunjukkan hasil uji korelasi antara tipe kepemimpinan autentik dengan kreativitas pegawai. Baris pertama pada tabel tersebut merupakan hasil estimasi korelasi dimana kreativitas menjadi variabel dependennya sementara tipe kepemimpinan autentik mejadi variabel independennya. Pada baris creativity (dependent) didapatkan hasil korelasi positif yang signifikan antara variabel tipe 
kepemimpinan autentik dengan variabel kreativitas $d=0.898 ; \mathrm{p}=0.047(\mathrm{p}<0.05)$. Hasil tersebut mendukung hipotesis penelitian yang diajukan sebelumnya.

Hasil pelaporan diri (self-report) partisipan pada instrumen kepemimpinan autentik dan kreativitas, digambarkan dalam grafik 1 dan 2 dibawah ini:

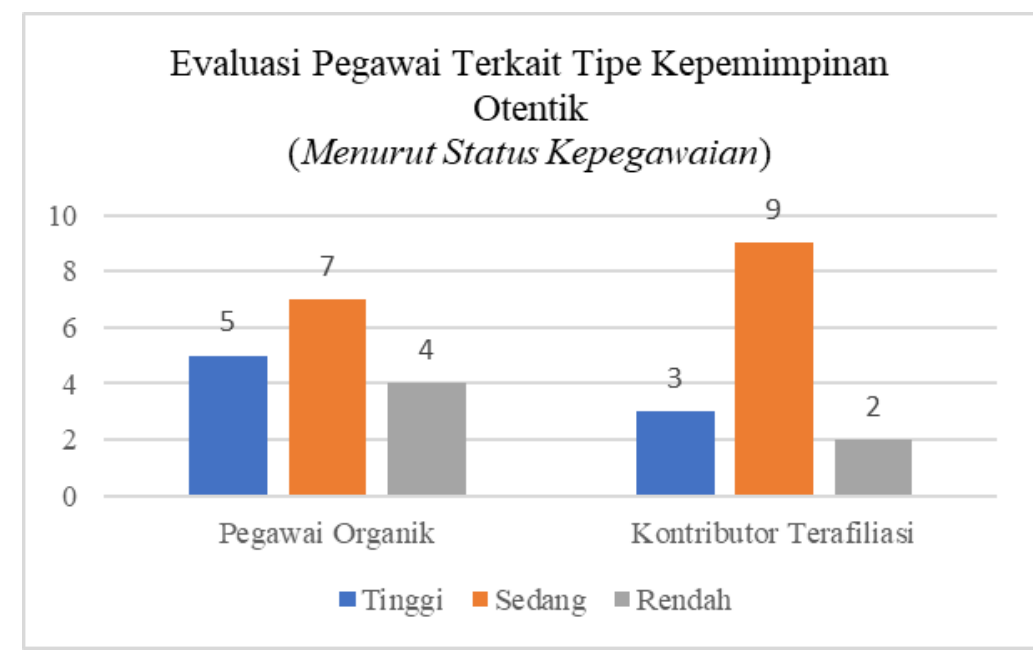

Grafik1

\section{Evaluasi Pegawai Terkait Tipe Kepemimpinan Autentik}

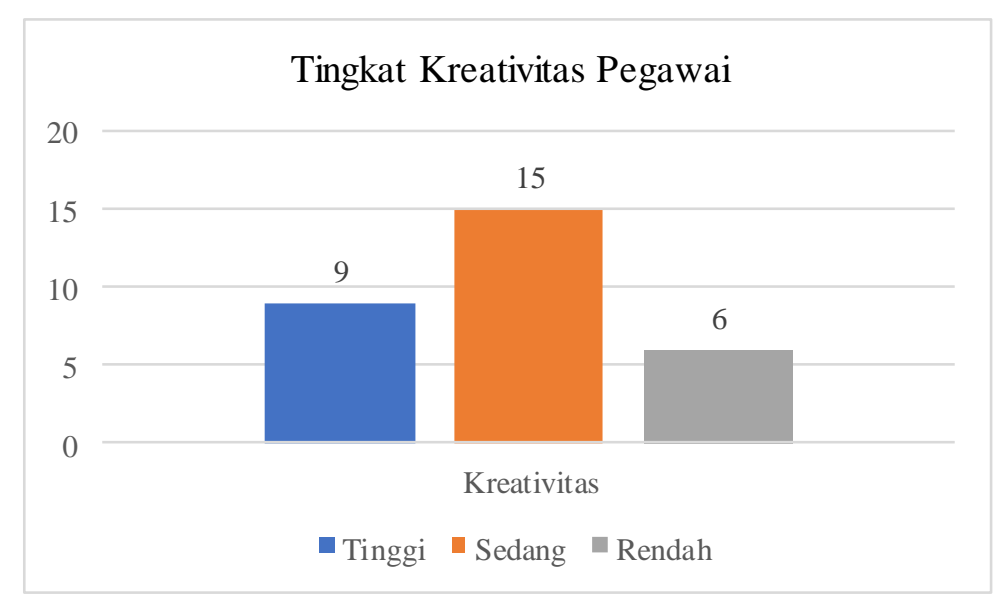

Grafik 2

Tingkat Kreativitas Pegawai

Mengacu pada Grafik 2 dapat dilihat kategori tingkat kreativitas partisipan. Pada grafik tersebut diketahui bahwa dari 30 partisipan yang terlibat dalam penelitian ini, terdapat 9 diantaranya yang memiliki kreativitas yang dengan kategori tinggi, 15 berada pada kategori sedang, dan 6 lainnya berada pada kategori rendah. Hubungan linier positif antara tipe kepemimpinan autentik dan kreativitas dapat dilihat pada grafik scatterplot (Grafik 3) yang menunjukkan bahwa semakin tinggi nilai pengukuran pada variabel tipe kepemimpinan autentik akan cenderung diikuti dengan peningkatan nilai pada variabel kreativitas. 


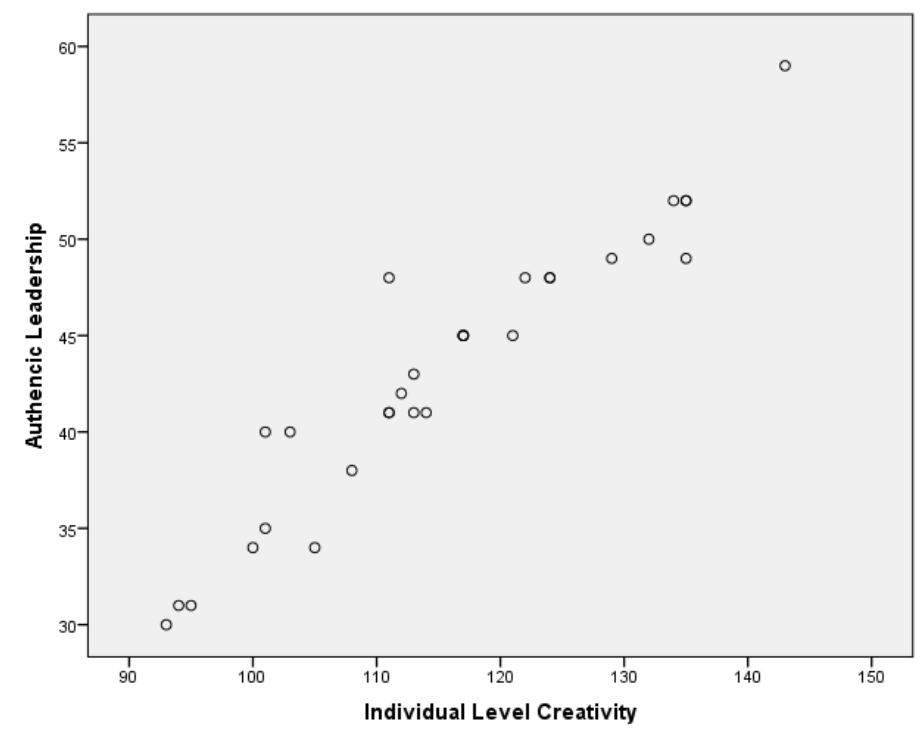

Grafik 3

\section{Scatterplot Tipe Kepemimpinan Autentik Dan Kreativitas Pegawai}

Kepemimpinan Autentik (Authentic Leadership) sangat penting dalam masyarakat saat ini, seiring dengan semakin berkurangnya jumlah pemimpin yang bisa menyertakan nurani dalam setiap tidakannya. (Walumbwa, Wang, Wang, Schaubroeck, \& Avolio, 2010) menyampaikan bahwa "semakin banyak pemimpin yang terlihat autentik, semakin banyak pegawai yang mengikuti mereka dan merasakan kedekatan psikologis, yang kemudian menjadi semakin melekat dengan peran mereka dalam menunjukkan perilaku mereka. Berfokus pada kepemimpinan, khususnya pada tipe kepemimpinan autentik akan membantu menciptakan hasil positif bagi para pemimpin dalam jangka panjang, baik bagi pegawai maupun organisasi atau institusinya.

Persepsi para pegawai terkait dengan pengaruh karakter kepemimpinan autentik yang ada dalam diri pemimpin terbukti mempengaruhi kreatifitas mereka. Hasil tersebut sesuai dengan studi yang menyatakan bahwa faktor tipe kepemimpinan merupakan salah satu determinan dari perlaku kreatif (Jaskyte \& Kisieliene, 2006). Secara spesifik disebutkan bahwa, autentisitas seorang pemimpin memiliki peran penting dalam kreativitas pegawai (Avolio, Luthans, \& Walumbwa, 2004); (Gardner, Avolio, Luthans, May, \& Walumbwa, 2005); (Ilies, Morgeson, \& Nahrgang, 2005); (Semedo et al., 2017). Semangat dan motivasi yang dimiliki oleh seorang pemimpin yang autentik diasumsikan dapat memberikan kontribusi pada kesuksesan dalam menjalin hubungan interpersonal dan menstimuli kemunculan ide-ide kreatif (Zhang, Tsui, \& Wang, 2011); (Rego, Vitória, Magalhães, Ribeiro, \& e Cunha, 2013).

\section{Kesimpulan}

Kepemimpinan autentik mungkin bukan fenomena terbaru, tapi saat ini, tipe pemimpin yang memimpin dengan integritas, kejujuran, etik dan perilaku moral seperti itu sangat diperlukan. Pemimpin perlu jujur pada dirinya sendiri dan untuk selanjutnya, menjadi sosok yang jujur bagi orang lain. Penelitian ini memberikan bukti tambahan 
bagi pengukuran validitas konstruk Authentic Leadership (AL) dan juga mendemonstrasikan hubungan antara AL dengan kreatifitas. Kontribusi pertama yang dipresentasikan dalam penelitian ini adalah untuk menunjukkan bukti adanya hubungan antara AL dan kreatifitas. Hasil penelitian ini mengindikasikan efek positif antara kepemimpinan dan kreatifitas. Temuan dalam penelitian mendukung dan memperkuat temuan dari beberapa peneliti sebelumnya yang menyatakan bahwa dimensi-dimensi dalam Authentic Leadership (AL), balanced processing, dan self awareness memiliki efek yang positif dalam kreatifitas. Selain itu, penelitian ini menyampaikan bahwa kekuatan karakter seorang pemimpin yang autentik dapat mempromosikan kreatifitas pada pegawai. Karakteristik-karakteristik yang ada pada pemimpin yang autentik dapat memfasilitasi para pegawai untuk menjelaskan ide-ide mereka dan keputusan yang mungkin akan meningkatkan kreativitas. Hasil tersebut didukung oleh temuan peneltian sebelumnya yang menyatakan bahwa faktor afeksi positif memiliki kontribusi terhadap perilaku positif ditempat kerja, termasuk kreativitas pegawai. Autentisitas diri yang ditampilkan oleh seorang pemimpin dapat berimplikasi pada kinerja organisasi secara umum. Temuan dalam penelitian ini dapat digunakan untuk kepentingan praktis dalam setting organisasi, khususnya pada proses seleksi pemimpin. Jika suatu organisasi memilih pemimpin mereka berdasarkan dimensi-dimensi kepemimpinan autentik, baik secara langsung maupun tidak, autentisitas pemimpin dapat menumbuhkan serta meningkatkan kreativitas pegawai yang berada didalam organisasi itu sendiri. 


\section{BIBLIOGRAFI}

Avolio, Bruce J., \& Gardner, William L. (2005). Authentic leadership development: Getting to the root of positive forms of leadership. The Leadership Quarterly, 16(3), 315-338. Google Scholar

Avolio, Bruce J., Luthans, Fred, \& Walumbwa, Fred O. (2004). Authentic leadership: Theory building for veritable sustained performance. Google Scholar

Bledow, Ronald, Rosing, Kathrin, \& Frese, Michael. (2013). A dynamic perspective on affect and creativity. Academy of Management Journal, 56(2), 432-450. Google Scholar

Bosiok, Delia. (2013). Leadership styles and creativity. Online Journal of Applied Knowledge Management (OJAKM), 1(2), 64-77. Google Scholar

Campbell, Tessa, Knox, Matthew Wayne, Rowlands, Josh, Cui, Zi Ying Anna, \& DeJesus, Luke. (2021). Leadership in FinTech: Authentic leaders as enablers of innovation and competitiveness in financial technology firms. In Fostering Innovation and Competitiveness With FinTech, RegTech, and SupTech (pp. 250270). IGI Global. Google Scholar

Gardner, William L., Avolio, Bruce J., Luthans, Fred, May, Douglas R., \& Walumbwa, Fred. (2005). "Can you see the real me?" A self-based model of authentic leader and follower development. The Leadership Quarterly, 16(3), 343-372. Google Scholar

George, Jennifer M., \& Zhou, Jing. (2007). Dual tuning in a supportive context: Joint contributions of positive mood, negative mood, and supervisory behaviors to employee creativity. Academy of Management Journal, 50(3), 605-622. Google Scholar

Guilford, Joy Paul. (1968). Intelligence, creativity, and their educational implications. Edits Pub. Google Scholar

Hebbeln, Elizabeth Bennett. (2020). Borrowing Methods: The Perceived Influence of Reflective Positionality Work in Local Television Journalists. University of Pennsylvania. Google Scholar

Herrmann, Daniel, \& Felfe, Jörg. (2014). Effects of leadership style, creativity technique and personal initiative on employee creativity. British Journal of Management, 25(2), 209-227. Google Scholar

Ilies, Remus, Morgeson, Frederick P., \& Nahrgang, Jennifer D. (2005). Authentic leadership and eudaemonic well-being: Understanding leader-follower outcomes. The Leadership Quarterly, 16(3), 373-394. Google Scholar

Isen, Alice M., Daubman, Kimberly A., \& Nowicki, Gary P. (1987). Positive affect facilitates creative problem solving. Journal of Personality and Social Psychology, 52(6), 1122. Google Scholar

Ishwara, Luwi. (2005). Catatan-catatan jurnalisme dasar (Vol. 1). Penerbit Buku 
Figur Pemimpin Autentik dalam Menunjang Kreativitas Pekerja Media di Industri

Televisi

Kompas. Google Scholar

Jaskyte, Kristina, \& Kisieliene, Audrone. (2006). Determinants of employee creativity: A survey of Lithuanian nonprofit organizations. Voluntas: International Journal of Voluntary and Nonprofit Organizations, 17(2), 128. Google Scholar

Khan, Shahid Nawaz. (2010). Impact of authentic leaders on organization performance. International Journal of Business and Management, 5(12), 167. Google Scholar

Mubarak, Fozia, \& Noor, Ayesha. (2018). Effect of authentic leadership on employee creativity in project-based organizations with the mediating roles of work engagement and psychological empowerment. Cogent Business \& Management, 5(1), 1429348. Google Scholar

Müceldili, Büşra, Turan, Haldun, \& Erdil, Oya. (2013). The influence of authentic leadership on creativity and innovativeness. Procedia-Social and Behavioral Sciences, 99, 673-681. Google Scholar

Rego, Arménio, Sousa, Filipa, Marques, Carla, \& e Cunha, Miguel Pina. (2012). Authentic leadership promoting employees' psychological capital and creativity. Journal of Business Research, 65(3), 429-437. Google Scholar

Rego, Arménio, Vitória, Andreia, Magalhães, Ana, Ribeiro, Neuza, \& e Cunha, Miguel Pina. (2013). Are authentic leaders associated with more virtuous, committed and potent teams? The Leadership Quarterly, 24(1), 61-79. Google Scholar

Riadi, Edi. (2016). Statistika penelitian (analisis manual dan IBM SPSS). Yogyakarta: Andi. Google Scholar

Semedo, Ana Suzete Dias, Coelho, Arnaldo Fernandes Matos, \& Ribeiro, Neuza Manuel Pereira. (2017). Authentic leadership and creativity: the mediating role of happiness. International Journal of Organizational Analysis. Google Scholar

Sugiyono, Sugiyono. (2010). Metode penelitian kuantitatif dan kualitatif dan R\&D. Alfabeta Bandung. Google Scholar

Walumbwa, Fred O., Avolio, Bruce J., Gardner, William L., Wernsing, Tara S., \& Peterson, Suzanne J. (2008). Authentic leadership: Development and validation of a theory-based measure. Journal of Management, 34(1), 89-126. Google Scholar

Walumbwa, Fred O., Wang, Peng, Wang, Hui, Schaubroeck, John, \& Avolio, Bruce J. (2010). Retracted: Psychological processes linking authentic leadership to follower behaviors. Elsevier. Google Scholar

Winston, Bruce E., \& Patterson, Kathleen. (2006). An integrative definition of leadership. International Journal of Leadership Studies, 1(2), 6-66. Google Scholar

Zhang, Ann Yan, Tsui, Anne S., \& Wang, Duan Xu. (2011). Leadership behaviors and group creativity in Chinese organizations: The role of group processes. The Leadership Quarterly, 22(5), 851-862. Google Scholar 
Chindy Y Subandrio dan Anissa Lestari Kadiyono

Zhou, Jing, \& George, Jennifer M. (2001). When job dissatisfaction leads to creativity: Encouraging the expression of voice. Academy of Management Journal, 44(4), 682-696. Google Scholar

Zhou, Jing, \& Shalley, Christina E. (2007). Handbook of organizational creativity. Taylor \& Francis. Google Scholar

\section{Copyright holder:}

Chindy Y Subandrio dan Anissa Lestari Kadiyono (2021)

First publication right:

Journal Syntax Literate

This article is licensed under:

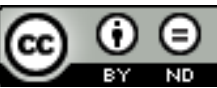

